\title{
Kualitas Fisik Daging Sapi Peranakan Simmental dengan Perlakuan Stimulasi Listrik dan Lama Pelayuan yang Berbeda
}

\section{Physical Quality of Simmental Cross Beef with Different Electric Stimulation and Chilling Period Treatments}

\author{
Rusdimansyah dan Khasrad \\ Program Studi Peternakan Fakutas Peternakan Universitas Andalas \\ email: rusdimanyah@gmail.com \\ (Diterima: 28 Agustus 2012 ; Disetujui: 14 Oktober 2012 )
}

\begin{abstract}
This research was conducted to observe the influence of electric stimulation and chilling period on meat of Simmental cross. This experiment used factorial design with 5 blocks. The first factor was electric stimulation (with and without electric stimulation), the second factor was chilling period (0, 12 and 24 hours). Around $7.5 \mathrm{~kg}$ Simmental cross meat (Tricep brachii) from 5 head were used on this research. The observed variables were $\mathrm{pH}$, cooking loss and tenderness. The results showed that there was no interaction of electric stimulation and chilling period (up to 24 hours) on all of observed variables. Electric stimulation treatment was significant improved tenderness of Simmental cross beef but it was not significant on $\mathrm{pH}$ and cooking loss. There was significant influenced of chilling period on $\mathrm{pH}$, cooking loss and tenderness of Simmental cross beef.
\end{abstract}

Key words: electric stimulation, chilling period, $\mathrm{pH}$, cooking loss, tenderness

\section{PENDAHULUAN}

Laju pertumbuhan penduduk yang cukup pesat berakibat pada peningkatan kebutuhan protein hewani. Peningkatan kebutuhan masyarakat terhadap protein hewani terutama daging, meningkat setiap tahunnya dan ini harus diimbangi dengan peningkatan produktivitas ternak. Salah satu permasalahan dalam usaha pemenuhan kebutuhan daging adalah produksi daging yang belum mencukupi kebutuhan masyarakat. Produksi daging nasional pada tahun 2011 mencapai 2,631 juta ton (Dirjen Peternakan, 2012). Ternak sapi merupakan salah satu sumber penghasil bahan pangan berupa daging yang memiliki nilai ekonomi tinggi. Untuk mendapatkan kualitas yang baik dari ternak sapi, maka perlu ditingkatkan produktivitas dan reproduktivitasnya. Salah satu faktor yang harus diperhatikan dalam hal ini adalah penggunaan bibit ternak yang berkualitas baik, agar diperoleh daging dengan mutu bagus.

Daging sapi merupakan salah satu bahan pangan asal hewan yang cukup disukai ma- syarakat untuk memenuhi kebutuhan protein hewani. Hal ini dikarenakan daging sudah dikenal sebagai salah satu bahan makanan yang hampir sempurna, karena mengandung zat gizi yang lengkap dan dibutuhkan oleh tubuh, yaitu protein hewani, energi, air, mineral dan vitamin serta memiliki rasa dan aroma yang enak. Saat ini, konsumen cukup selektif dalam memilih daging, sehingga perlu diupayakan beberapa usaha untuk meningkatkan kualitas daging sapi. Beberapa usaha yang dapat dilakukan untuk meningkatkan kualitas daging adalah dengan memberi perlakuan stimulasi listrik dan pelayuan daging setelah pemotongan (Soeparno, 2005).

Beberapa penelitian mendapatkan bahwa stimulasi listrik dapat memperpendek waktu rigormortis dan meningkatkan kualitas daging. Perlakuan stimulasi listrik dengan tegangan 110 volt dan 220 volt dapat meningkatkan kualitas daging sapi Pesisir, dilihat dari peningkatan keempukan daging, penurunan pH cepat, penurunan kadar air dan kadar lemak (Yetmaneli dan Susanti, 2009). Pelayuan pada daging juga dapat meningkatkan 
keempukan dan flavor daging (Soeparno, 2005). Stimulasi listrik dan pelayuan terhadap daging telah dikenal mampu meningkatkan kualitas daging sapi dan kerbau. Namun selama ini perlakuan stimulasi listrik maupun pelayuan terhadap daging masih dilakukan secara terpisah. Berdasarkan permasalahan tersebut maka dilakukan penelitian yang bertujuan untuk mengetahui tingkat interaksi dari perlakuan stimulasi listrik dan pelayuan terhadap kualitas daging sapi peranakan Simmental.

\section{METODE}

\section{Materi Penelitian.}

Penelitian ini menggunakan $7,5 \mathrm{~kg}$ daging sapi peranakan Simmental (dari 5 ekor sapi) jantan yang dipotong di RPH Bandar Buat. Pengambilan sampel dilakukan pada otot Tricep brachii.

\section{Pelaksanan Penelitian}

Prosedur penanganan sapi sebelum pemotongan mengikuti penanganan sapi di RPH Bandar Buat, setelah disembelih, lalu diambil daging dari otot Tricep brachii $\pm 1,5 \mathrm{~kg}$ (dari tiap ekor sapi). Bagian otot ini dibagi menjadi 2 bagian dan salah satu bagian diberi perlakuan stimulasi listrik dengan tegangan 220 volt. Selanjutnya masing-masing bagian (stimulasi listrik dan tanpa stimulasi listrik) dibagi lagi menjadi 3 bagian lalu sampel dengan total 6 bagian tersebut dibawa ke Laboratorium Ternak Potong untuk mendapatkan pelakuan pelayuan dengan menggunakan suhu (0-3 C), selanjutnya dilakukan pengukuran peubah yang diamati.

\section{Peubah yang Diamati pH daging}

Analisis pH daging menggunakan metode Apriyanto et al. (1989). Prosedur kerjanya adalah sebagai berikut : $10 \mathrm{~g}$ sampel daging dihaluskan, kemudian ditambahkan $20 \mathrm{ml}$ aquades lalu diaduk rata dan kemudian didiamkan \pm 15 menit. Kemudian $\mathrm{pH}$ daging diukur dengan $\mathrm{pH}$ meter dengan cara mencelupkan ujung katoda. Daging yang telah dimasukan ke dalam aquades diaduk-aduk setelah itu dibiarkan selama 15 menit.

\section{Susut Masak (\%)}

Pengujian susut masak dilakukan prosedur kerja sebagai berikut: Daging dipotong menjadi sampel dengan ukuran berat \pm 100 gram, kemudian direbus sampai suhu dalam daging $81^{\circ} \mathrm{C}$. Angkat daging dan didinginkan, dilap dengan tissue dan dilakukan penimbangan kembali untuk mendapatkan berat daging setelah dimasak.

Penghitungan berat yang hilang selama pemasakan atau susut masak adalah menurut Separno (2005).

\section{Keempukan Daging $\left(\mathrm{kg} / \mathrm{cm}^{2}\right)$}

Pengukuran keempukan daging sapi dilakukan menggunakan alat pemutus warner-bratzler (WB), daging direbus sampai temperatur dalam daging mencapai angka $81^{\circ} \mathrm{C}$, kemudian daging diangkat dan didinginkan. Sampel daging dibuat menjadi berbentuk balok empat persegi panjang dengan potongan searah serabut otot. Pengujian daya putus otot, dengan luas penampang sampel adalah $1,5 \times 0,67 \mathrm{~cm}=1 \mathrm{~cm}^{2}$ (Soeparno, 2005)

\section{Analisis Data}

Penelitian ini menggunakan percobaan berfaktor 2x3 dalam blok. Faktor I adalah stimulasi listrik ( $\mathrm{a}_{0}=$ tanpa stimulasi listrik, $\mathrm{a}_{1}=$ dengan stimulasi listrik), faktor ke-2 adalah lama pelayuan $\left(b_{0}=0\right.$ jam, $b_{1}=12$ jam, $b_{2}=24$ jam). Model linier aditif yang digunakan adalah menurut Mattjik dan Sumertajaya (2006). Data yang diperoleh dianalisis dengan analisis sidik ragam (ANOVA), jika terdapat pengaruh terhadap peubah yang diukur maka akan dilanjutkan dengan uji Duncan.

\section{Tempat dan Waktu Penelitian}

Penelitian ini dilakukan dilaksanakan di Laboratorium Ternak Potong Fakultas Peternakan Universitas Andalas pada Juni s/d Juli 2012.

\section{HASIL DAN PEMBAHASAN}

\section{pH Daging}

Rataan $\mathrm{pH}$ daging sapi peranakan Simmental hasil penelitian ditunjukkan pada Tabel 1. 
Tabel 1. Rataan pH Daging Sapi Peranakan Simmental dengan Stimulasi Listrik dan Lama Waktu Pelayuan

\begin{tabular}{cccc}
\hline \multirow{2}{*}{$\begin{array}{c}\text { Lama Pelayuan } \\
(\text { Jam })\end{array}$} & \multicolumn{2}{c}{ Stimulasi } & \multirow{2}{*}{ Rataan } \\
\cline { 2 - 3 } & Stimulasi & Tanpa stimulasi & \\
\hline 0 & $5,89 \pm 0,11$ & $5,88 \pm 0,05$ & $5,89 \pm 0,08^{\mathrm{a}}$ \\
12 & $5,67 \pm 0,25$ & $5,67 \pm 0,15$ & $5,67 \pm 0,20^{\mathrm{b}}$ \\
24 & $5,61 \pm 0,23$ & $5,68 \pm 0,15$ & $5,65 \pm 0,18^{\mathrm{b}}$ \\
\hline Rataan & $5,73 \pm 0,23$ & $5,74 \pm 0,15$ & $5,73 \pm 0,19$ \\
\hline
\end{tabular}

Keterangan: Angka dengan superskrip yang berbeda pada kolom yang sama menunjukkan hasil yang berbeda nyata $(\mathrm{P}<0,05)$

Analisis statistik menunjukan bahwa tidak terdapat interaksi antara stimulasi listrik dengan lama pelayuan $(\mathrm{P}>0,05)$, faktor stimulasi listrik tidak berpengaruh nyata $(\mathrm{P}>0,05)$ terhadap $\mathrm{pH}$, sedangkan faktor lama pelayuan memberikan pengaruh yang berbeda nyata $(\mathrm{P}<0,05)$ terhadap nilai rataan $\mathrm{pH}$ daging sapi peranakan simmental

Berdasarkan faktor tunggal perlakuan, faktor stimulasi listrik tidak berpengaruh terhadap nilai $\mathrm{pH}$ daging sapi peranakan Simmental, hal ini terlihat dari nilai rataan $\mathrm{pH}$ pada daging yang diberi perlakuan stimulasi dan tanpa stimulasi listrik menunjukkan perbedaan yang tidak signifikan dengan nilai rataan berturut-turut 5,73 $\pm 0,23$ dan 5,74 $\pm 0,15$. Hal ini disebabkan pengaruh antemortem atau faktor sebelum pemotongan yakni stres pada ternak sebelum pemotongan.

Hasil ini mendukung pendapat Bouton et al. (1971) dalam Soeparno (2005) bahwa stres sebelum pemotongan, injeksi adrenalin, atau insulin dan tremolin akan menghasilkan $\mathrm{pH}$ daging ultimat yang tinggi karena cadangan glikogen otot menjadi cepat habis. Swatland (1984) menyatakan bahwa resistensi karkas terhadap perlakuan stimulasi listrik dipengaruhi oleh beberapa faktor sebagai berikut; (1) tenggang waktu antara pemotongan ternak dengan stimulasi listrik, (2) jarak antara elektroda, (3) kontak area permukaan elektroda dengan daging, (4) ukuran karkas, apakah karkas utuh, belahan karkas atau potongan karkas, (5) lokasi stimulasi listrik, (6) lama waktu dan voltase stimulasi listrik.

Faktor lama pelayuan memperlihatkan pengaruh yang nyata $(\mathrm{P}<0,05)$ pada nilai $\mathrm{pH}$ daging sapi. Rataan $\mathrm{pH}$ daging dengan perlakuan lama pelayuan yang berbeda $(0,12$, dan 24 jam) berturut-turut adalah 5,89 $\pm 0,08$; $5,67 \pm 0,20$ dan 5,65 $\pm 0,18$. Hasil ini menunjukkan bahwa lama pelayuan sampai 24 jam dapat menurunkan $\mathrm{pH}$. Menurut Soeparno (2005), setelah hewan dipotong akan terjadi penurunan $\mathrm{pH}$ pada daging, $\mathrm{pH}$ ultimat akan tercapai setelah 24 jam setelah pemotongan. Menurut pendapat Forrest et al. (1975) yang menyatakan bahwa penurunan $\mathrm{pH}$ terjadi karena terhentinya aliran darah sehingga suplai oksigen juga terhenti dan tidak tersedianya oksigen untuk menangkap ion hydrogen yang dibebaskan dalam proses glikolisis dan siklus TCA (tricarboxylic acid).

Nilai $\mathrm{pH}$ pada pelayuan 0 jam lebih tinggi dibandingkan dengan pelayuan 12 jam dan 24 jam, disebabkan pada perlakukan ini $\mathrm{pH}$ daging baru mengalami penurunan awal pada $\mathrm{pH}$. Penurunan $\mathrm{pH}$ dari daging akan dipengaruhi oleh kondisi ternak sebelum dipotong. Hasil ini sesuai dengan pendapat Soeparno (2005), yang menyatakan bahwa ternak yang mengalami perjalanan jauh, sebelum dipotong harus diistirahatkan dan kemudian dipuasakan selama 12-18 jam.

Pelayuan selama 12 dan 24 jam tidak menunjukkan perbedaan nyata, hal ini disebabkan nilai $\mathrm{pH}$ daging pada pelayuan 12 jam sudah mendekati $\mathrm{pH}$ ultimat sehingga pada pelayuan 24 jam tidak mengalami penurunan $\mathrm{pH}$ yang terlalu besar. Biasanya $\mathrm{pH}$ ultimat didapat saat glikogen tidak ditemukan lagi pada daging. Hasil ini sesuai dengan pernyataan Lawrie (2003) yang menyatakan bahwa glikogen tidak ditemukan pada $\mathrm{pH}$ an- 
tara 5,4-5,5 dan biasanya $\mathrm{pH}$ ultimat dipengaruhi oleh enzim-enzim glikolitik. $\mathrm{pH}$ ultimat daging adalah $\mathrm{pH}$ yang tercapai setelah glikogen otot menjadi habis atau setelah enzim-enzim glikolitik menjadi tidak aktif pada $\mathrm{pH}$ rendah atau setelah glikogen tidak lagi sensitif terhadap serangan-serangan enzim glikolitik. Menurut Aberle et al. (2001) nilai $\mathrm{pH}$ otot setelah hewan mati akan menurun dari 7,4 (awal) menjadi 5,6-5,7 pada jam ke-6 sampai jam ke-8, kemudian nilai $\mathrm{pH}$ tersebut akan menurun mencapai $\mathrm{pH}$ akhir sekitar 5,3-5,7 pada jam ke-24 postmortem.

Nilai $\mathrm{pH}$ awal daging biasanya diperoleh dalam waktu 45 menit setelah pemotongan. Untuk mendapatkan $\mathrm{pH}$ akhirnya, $\mathrm{pH}$ daging diukur setidak-tidaknya setelah 24 jam. Hal ini sesuai dangan pendapat Soeparno (2005) yang menyatakan bahwa $\mathrm{pH}$ daging tidak dapat diukur segera setelah pemotongan (biasanya dalam waktu 45 menit) untuk mengetahui penurunan $\mathrm{pH}$ awal. Pengukuran selanjutnya biasa dilakukan setidak-tidaknya setelah 24 jam untuk mengetahui $\mathrm{pH}$ akhir daging.

\section{Susut masak}

Susut masak merupakan fungsi dari temperatur dan lama pemasakan. Disamping itu susut masak bisa dipengaruhi oleh $\mathrm{pH}$, panjang sarkomer serabut otot, panjang potongan serabut, status kotraksi myofibril, ukuran dan berat sampel daging dan penampang lintang daging (Bouton et al.,1978).

Nilai rataan susut masak daging sapi peranakan Simmental dari perlakuan stimulasi listrik dan lama pelayuan dapat dilihat pada Tabel 2. Analisis sidik ragam menunjukkan bahwa tidak ada pengaruh interaksi antara stimulasi listrik dengan lama pelayuan dan faktor tunggal stimulasi listrik terhadap nilai susut masak, sedangkan pada faktor lama pelayuan memiliki perbedaan yang nyata $(\mathrm{P}<0,05)$ terhadap nilai persentase susut masak daging sapi peranakan Simmental.

Analisis sidik ragam menunjukkan bahwa tidak ada pengaruh interaksi antara stimulasi listrik dengan lama pelayuan dan faktor tunggal stimulasi listrik terhadap nilai su- sut masak, sedangkan pada faktor lama pelayuan memiliki perbedaan yang nyata $(\mathrm{P}<0,05)$ terhadap nilai persentase susut masak daging sapi peranakan Simmental.

Faktor stimulasi listrik tidak berpengaruh nyata $(\mathrm{P}>0,05)$ dengan nilai persentase susut masak pada perlakuan tanpa stimulasi dan dengan stimulasi listrik berturut-turut sebesar $33,51 \pm 3,20 \%$ dan $35,24 \pm 2,41 \%$. Hal ini disebabkan tingkat stres pada ternak dan juga terlihat pada nilai rataan $\mathrm{pH}$ (Tabel 1). Nilai $\mathrm{pH}$ antara perlakuan stimulasi listrik dan tanpa stimulasi listrik menunjukkan tidak berbeda nyata secara statistik. Hasil ini menunjukkan bahwa perlakuan stimulasi listrik tidak berpengaruh terhadap nilai susut masak daging sapi peranakan Simmental. Hal ini dikarenakan $\mathrm{pH}$ daging juga berhubungan dengan susut masak daging. Ini sesuai dengan pendapat Soeparno (2005) yang menyatakan bahwa $\mathrm{pH}$ daging yang berhubungan dengan daya ikat air, kesan jus daging, keempukan dan susut masak, juga biasa berhubungan dengan warna dan sifat mekanik daging (daya putus WB, kompresi, adhesi dan kekuatan tarik), kenaikan $\mathrm{pH}$ daging akan meningkatkan jus daging (kenyataan jus dan daya ikat air) dan menurunkan susut masak otot SM dan LD domba secara linear. Faktor lama pelayuan berpengaruh nyata $(\mathrm{P}<0,05)$ terhadap nilai susut masak. Persentase susut masak untuk pelayuan 0,12 , dan 24 jam berturut-turut adalah sebesar $32,79 \pm 3,30,33,79 \pm 1,84$ dan $36,55 \pm 2,19 \%$. Hal ini disebabkan pengaruh daya ikat air yang terlalu besar selama waktu pelayuan sehingga pada proses thawing tidak berlangsung dengan baik dan hal ini juga dipengaruhi oleh lamanya waktu thawing. Waktu thawing juga harus diperhatikan, karena lama pelayuan harus dibedakan juga waktu penyegarannya hal ini disebabkan jumlah cairan yang terdapat pada daging dengan pelayuan 0, 12 dan 24 jam juga berbeda.

\section{Keempukan}

Keempukan merupakan faktor penting yang dipertimbangkan dalam atribut palatibilitas daging dan berkaitan erat dengan tingkat penerimaan konsumen (Chambers dan 
Tabel 2. Rataan Susut Masak Daging Sapi Peranakan Simmental dengan Perlakuan Stimulasi Listrik dan Lama Waktu Pelayuan (\%)

\begin{tabular}{cccc}
\hline \multirow{2}{*}{$\begin{array}{c}\text { Lama Pelayuan } \\
\text { (jam) }\end{array}$} & \multicolumn{2}{c}{ Stimulasi } & \multirow{2}{*}{ Rataan } \\
\cline { 2 - 3 } & Stimulasi & Tanpa stimulasi & $32,79 \pm 3,30^{\mathrm{a}}$ \\
12 & $31,46 \pm 3,45$ & $34,12 \pm 2,87$ & $33,79 \pm 1,84^{\mathrm{ab}}$ \\
24 & $32,61 \pm 1,39$ & $34,96 \pm 1,49$ & $36,55 \pm 2,19^{\mathrm{b}}$ \\
\hline Rataan & $36,45 \pm 2,24$ & $36,65 \pm 2,40$ & $34,38 \pm 2,92$ \\
\hline
\end{tabular}

Keterangan :Angka dengan super skrip yang berbeda pada kolom yang sama menunjukkan hasil yang berbeda nyata $(\mathrm{P}<0,05)$

Tabel 3. Rataan Keempukan Daging Sapi Peranakan Simmental dengan Perlakuan Stimulasi Listrik dan Lama Pelayuan $\left(\mathrm{kg} / \mathrm{cm}^{2)}\right.$

\begin{tabular}{cccc}
\hline \multirow{2}{*}{$\begin{array}{c}\text { Lama Pelayuan } \\
(\text { Jam })\end{array}$} & \multicolumn{2}{c}{ Stimulasi } & Rataan \\
\cline { 2 - 3 } & Stimulasi & Tanpa stimulasi & \\
\hline 0 & $6,92 \pm 1,31$ & $8,47 \pm 0,92$ & $7,69 \pm 1,34^{\mathrm{a}}$ \\
12 & $8,98 \pm 0,88$ & $10,18 \pm 0,26$ & $9,58 \pm 0,88^{\mathrm{b}}$ \\
24 & $7,88 \pm 2,40$ & $8,91 \pm 1,48$ & $8,40 \pm 1,95^{\mathrm{ab}}$ \\
\hline Rataan & $7,93 \pm 1,76^{\mathrm{b}}$ & $9,19 \pm 1,21^{\mathrm{a}}$ & $8,56 \pm 1,62$ \\
\hline
\end{tabular}

Keterangan :Angka dengan super skrip yang berbeda pada kolom/baris yang sama menunjukkan hasil yang berbeda nyata $(\mathrm{P}<0,05)$

Bower, 1993). Keempukan sering kali menyebabkan ketidakpuasan konsumen terhadap kualitas daging sapi (Purchas et al., 2002). Menurut (Suryati et al., 2008) keempukan sangat berkaitan dengan penerimaan konsumen terhadap produk olahan daging. Berdasarkan hal tersebut dapat dipastikan bahwa keempukan merupakan hal penting yang harus diperhatikan dalam industi daging dan pengolahannya.

Nilai rataan keempukan daging sapi peranakan Simmental dengan perlakuan stimulasi listrik dan pelayuan dapat dilihat pada Tabel 3. Analisis sidik ragam menunjukkan tidak ada pengaruh interaksi antara perlakuan stimulasi listrik dan pelayuan $(\mathrm{P}>0,05)$, sedangkan faktor tunggal stimulasi listrik dan lama pelayuan berpengaruh nyata terhadap keempukan daging sapi peranakan Simmental.
Faktor stimulasi listrik berpengaruh nyata $(\mathrm{P}<0,05)$ terhadap keempukan daging sapi peranakan Simmental, dimana nilai daya putus yang menggunakan alat Warner Bratzler untuk daging yang diberi stimulasi listrik $(7,93 \pm 1,76)$ lebih rendah dibandingkan dengan tanpa pemberian stimulasi listrik $(9,19 \pm 1,21)$. Hal ini disebabkan daging yang mendapat perlakuan stimulasi listrik akan mencegah pemendekan otot sehingga otot yang dihasilkan menjadi regang dan mempercepat laju glikolisis postmortem sehingga mampu menghasilkan daging dengan tingkat keempukan yang lebih tinggi.

Hasil ini sesuai dengan pendapat McCollum dan Henrickson (1977) dalam Soeparno (2005), yang menyatakan bahwa stimulasi listrik mampu mempercepat glikolisis postmortem, mencegah pemendekan otot karena temperatur dingin yang disebut cold 
shortening dan meningkatkan keempukan daging pada domba serta mampu memperbaiki keempukan serta flavor pada daging sapi.

Faktor lama pelayuan berpengaruh nyata $(\mathrm{P}<0,05)$ terhadap keempukan daging. Hal ini terlihat dari nilai daya putus pada 0,12 dan 24 jam berturut-turut adalah sebesar $7,69 \pm 1,34,9,58 \pm 0,88$ dan $8,40 \pm 1,95$. Faktor yang menyebabkan terjadinya peningkatan nilai daya putus dari 0,12 dan 24 jam dipengaruhi oleh $\mathrm{pH}$, dimana $\mathrm{pH}$ pada 0 jam lebih tinggi dibandingkan dengan $\mathrm{pH}$ pada pelayuan 12 dan 24 jam, sehingga pada $\mathrm{pH}$ yang tinggi tingkat keempukannya lebih tinggi. Hasil ini sesuai dengan pendapat Penny et al. (1963); Bouton et al. (1971) yang menyatakan bahwa daging dengan $\mathrm{pH}$ tinggi mempunyai keempukan yang lebih tinggi dari pada daging dengan $\mathrm{pH}$ rendah.

Hasil berbeda didapatkan oleh Forrest et al. (1975) yang menyatakan bahwa meningkatnya keempukan daging selama pelayuan terutama pada suhu $4^{\circ} \mathrm{C}$ selama seminggu disebabkan penurunan $\mathrm{pH}$ daging sehingga enzim-enzim katepsin menjadi aktif dan dapat memecah protein daging, akibatnya daging menjadi lebih empuk.

Terjadinya peningkatan nilai daya putus yang terlalu besar pada lama pelayuan 12 jam yaitu karena daya ikat air yang terlalu besar dan tidak terlalu didukung dengan lama waktu pelayuan, sehingga pada proses thawing jumlah cairan yang keluar tidak sempurna atau keluar secara keseluruhan dan juga mempengaruhi jus daging selama pemasakan berlangsung.

Hasil penelitian ini sesuai dengan pendapat Soeparno (2005), yang mengemukakan bahwa hilangnya cairan pada saat penyegaran kembali sebagai drip akan menurunkan daya ikat air daging, sehingga mempengaruhi jus daging masak.

\section{KESIMPULAN}

Dari hasil penelitian ini dapat disimpulkan bahwa tidak ada pengaruh interaksi antara perlakuan stimulasi listrik dengan lama pelayuan terhadap nilai $\mathrm{pH}$, susut masak dan keempukan daging sapi peranakan Simmental. Perlakuan stimulasi listrik dapat meningkatkan keempukan daging namun tidak berpengaruh pada $\mathrm{pH}$ dan susut masak. Lama pelayuan sampai 24 jam dapat menurunkan $\mathrm{pH}$ serta meningkatkan susut masak dan tidak berpengaruh terhadap keempukan daging sapi peranakan Simmental.

\section{DAFTAR PUSTAKA}

Aberle, E. D., J. C., Forrest, D. E., Gerrard and E. W. Mills. 2001. Principles of Meat Science. W. H/Freeman and Co. San Fransisco.

Apriyanto, A.D., Fardiaz, N.L., Puspitasari., Sedamawati., dan S. Budiyanto. 1989. Analisa Pangan. PAU dan pangan Gizi. IPB Pres

Bouton, P.E., A.L. Ford, P.V. Harris dan F.D. Shaw. 1978. Effect of low voltage stimulation of beef carcasses on muscle tenderness and pH. J. Fd. Sci. 43:13921396.

Chamber.E., and J.R. Bower. 1993. Consumer preconception of sensory quality in muscles food. Food technology 47: 116120

Direktorat Jenderal Peternakan . 2011. Statiktik peternakan dan kesehatan hewan 201. Live Stock and Animal Healt Statistic. http://Ditjennak.deptan. go.id. Di akses tanggal 24 Agustus 2012. 20:35

Forrest, G.J., Aberle, H.B. Hendrick, M.D. Judge dan R.A. Merkel. 1975. Principles of Meat Science. W.H. Freeman and Company, San Francisco.

Lawrie RA. 2003. Ilmu Daging. Edisi Kelima.

Terjemahan: Parakkasi. Jakarta: Universitas Indonesia

McCollum, P.D. dan R.L. Henrickson. 1977. In Animal Science Research Report. 
Editor R.H. Thayer dan J.R. Cozart. Oklahoma State University dan USDA.

Mattjik, A.A dan I.M. Sumertajaya. 2006. Perancangan Percobaan dengan Aplikasi SAS dan Minitab. IPB. Bogor.

Purchas, R.W., D.L. Burham and S.T. Morris. 2002. Efects of growth potential and growthpath on tenderness of beef logissimus muscle from bulls and steer. Journal of Animal Science. 80:32113221

Soeparno. 1995. Ilmu dan Teknologi Daging. Gajah Mada University Press. Yogya karta.

Suryati, T., I. I. Arif and B.N. Polii. 2008. Correlation and categories of meat tenderness based on aquipment and panelis test. Journal of Animal Production. 3: 188-193.

Swatland, H.J. 1984. Strukture and Development of Meat Animals. Prentice-Hall, Inc., Englewood Cliffs, New Jersey.

Yetmaneli dan H. Susanty. 2009. Peningkatan kualitas daging sapi melalui penerapan teknologi stimulasi listrik. Lembaga Penelitian Universitas Andalas. Padang 